\title{
The Effect of Gas Diffusion Layer PTFE Content on The Performance of High Temperature Proton Exchange Membrane Fuel Cell
}

\author{
Huaneng Su*, Cordellia Sita, Sivakumar Pasupathi \\ HySA Systems Competence Centre, South African Institute for Advanced Materials Chemistry \\ (SAIAMC), University of the Western Cape, Robert Sobukwe Road, Bellville 7535, Cape Town, \\ South Africa \\ *E-mail: suhuaneng@gmail.com
}

doi: $10.20964 / 110402919$

Received: 14 October 2015 / Accepted: 10 January 2015 / Published: 1 March 2016

\begin{abstract}
Gas diffusion layer (GDL) with different polytetrafluoroethylene (PTFE) contents in the carbon substrate and the micro-porous layer (MPL) were investigated for the application in poly(2,5benzimidazole) (ABPBI)-based high temperature polymer electrolyte membrane fuel cell (HTPEMFC). The physical properties of the GDLs were characterized by scanning electron microscopy (SEM) and pore size distribution. The electrochemical properties of the single cell based on these GDLs were evaluated and analyzed by I-V curve and electrochemistry impedance spectroscopy (EIS). The results showed the use of a minimal quantity of PTFE in the carbon substrate $(\sim 15 \mathrm{wt} \%)$ and the MPL ( $~ 5-10 \mathrm{wt} \%)$ are suggested for both good mechanical properties of the GDLs and the good fuel cell performance.
\end{abstract}

Keywords: High temperature proton exchange membrane fuel cell, Polybenzimidazole, Gas diffusion layer, Micro-porous layer, PTFE loading, Cell performance

\section{$\underline{\text { FULL TEXT }}$}

(C) 2016 The Authors. Published by ESG (www.electrochemsci.org). This article is an open access article distributed under the terms and conditions of the Creative Commons Attribution license (http://creativecommons.org/licenses/by/4.0/). 